Lewowicki, Tadeusz. „Cztery spojrzenia na wielokulturowość i edukację międzykulturową". Pogranicze. Studia Społeczne 17 (2011): 28-35.

„Living together with the Other” Education \& Religion in a European Context Berlin, 5 to 8 October 2005. http://www.cogree.com/conferences/berlin/Programme.pdf.

Nowak, Marian. „Kulturowa inspiracja chrześcijańska a wychowanie”. W: Wychowanie chrześcijańskie a kultura, red. Marian Nowak, Tomasz Ożóg, 21-47. Lublin: RW KUL, 2000.

Possenti, Vittorio. Filozofia i wiara. Kraków: WAM, 2004.

Religijność i duchowość - dawne i nowe formy, red. Maria Libiszowska-Żółtkowska, Stella Grotowska. Kraków: Nomos, 2010.

Socha, Paweł M. Przemiana. W stronę teorii duchowości. Kraków: Nomos, 2014. Zdybicka, Zofia. Człowiek i religia. Zarys filozofii religii. Lublin: TN KUL, 1994.

\title{
Piotr Magier, Esej postantypedagogiczny, Lublin: Towarzystwo Naukowe KUL, 2016, s. 290.
}

\section{DOI: http://dx.doi.org/10.12775/PCh.2017.038}

Praca jest wynikiem studiów Autora nad anty- lub postpedagogiką, obecną w pedagogice współczesnej od początku lat siedemdziesiątych dwudziestego wieku. Wprawdzie, jak sam zauważa, ,natężenie dyskusji wywołanej pojawieniem się antypedagogiki w Polsce osłabło (szczególne zainteresowanie antypedagogiką przypada na przełom XX i XXI wieku)" (s. 8), to jednak w jego przekonaniu ,problemy wówczas postawione nie zostały satysfakcjonująco rozwiązane" (tamże). Publikacja jest zatem potrzebna i stanowi konieczne dopełnienie naukowego dyskursu nad tym zjawiskiem (,fenomenem"). Zawiera w sobie bardzo wnikliwą analizę podłoża, na którym wyrosło i z którego czerpało inspiracje, a także wielowątkową i szczegółową krytykę ${ }^{1}$. Wprawdzie określeniem współwystępującym dla antypedagogiki

${ }^{1}$ Książka składa się z „Wprowadzenia” (s. 7-10), „Wstępu” (s. 11-24), dwóch części, opisowej (rozdz. 1-3) i polemicznej (rozdz. 4): Rozdz. 1: „Definicyjna charakterystyka antypedagogiki” (s. 25-79); Rozdz. 2: „Paradygmat pedagogiki” (s. 81-143); Rozdz. 3: „Rekonstrukcja antropologicznych tez postpedagogiki” (s. 145-191); Rozdz. 4: „Postpedagogika we współczesnym dyskursie humanistycznym” (s. 193-248). Całość dopełnia „Zakończenie” (s. 249-254), bogata i umiejętnie podzielona „Bibliografia” (s. 255-278), streszczenie w języku angielskim (s. 279-281), „Indeks nazwisk” (s. 283-290). 
jest postpedagogika, które brzmi obiecująco i pozwala myśleć, że ona już nie istnieje, to jednak tak nie jest. „Wbrew potocznym - pisze Piotr Magier przekonaniom «abstrakcyjne», «oderwane od rzeczywistości» teorie nie pozostają «zamknięte» wyłącznie w sferze nauki, ale wpływają na cele, treści, metody, praktyki wychowawcze. Teoria decyduje o sposobie postrzegania rzeczywistości, a w konsekwencji warunkuje ludzkie wybory i działanie" (s. 11-12). Tym bardziej, że żyjemy w czasie, gdy «abstrakcyjne» i «oderwane od rzeczywistości» pomysły na wzór «nowych szat króla» wciąż się prezentuje: teoretyczne «osadzenie» antypedagogiki stanowi głównie postmodernizm oraz humanizm" (s. 81).

Autor uprzedza Czytelnika koniecznymi dopełnieniami, które pomogą lepiej wniknąć w omawiane treści. Są to:

- książka poświęcona jest (w zasadzie) koncepcji Hubertusa von Schoenebecka, jednego z liderów antypedagogiki,

- nie jest monografią, choć zawiera wiele informacji definicyjnych, lecz jest badaniem aspektowym,

- prezentowane badania aspirują do realizacji celów poznawczych i praktycznych: opisowo-wyjaśniających oraz ocennych (wartościujących i normatywnych),

- omawiane badania mają charakter interdyscyplinarny (s. 16-17).

W przekonaniu Autora w prezentowanej publikacji Czytelnik powinien znaleźć odpowiedzi na następujące pytania:

- co to jest antypedagogika?,

- jakie rozumienie terminu ,człowiek” funkcjonuje w antypedagogice oraz jakie tezy antropologiczne formuluje antypedagogika?,

- jakie są relacje pomiędzy antypedagogicznym rozumieniem istoty człowieka a humanistycznym i postmodernistycznym rozumieniem człowieka?,

- jakie sposoby argumentowania przyjmuje się $\mathrm{w}$ antypedagogice? (s. 17).

Odpowiedź na te pytania wyznaczają tok omówienia przedstawionej tu publikacji.

1. Istnieje kilka określeń bliskoznacznych lub synonimicznych wiązanych z terminem ,,antypedagogika”, jak na przykład: ,postpedagogika”, „przyjaźń z dziećmi”, „wspieranie zamiast wychowania”, „Amication”, „pedagogika negatywna” (s. 70); niektóre się pokrywają, a innym razem są celowo rozróżniane, jak na przykład ,,antypedagogika” i ,postpedagogika”. Ta ostatnia byłaby „częścią (typem) antypedagogiki” (s. 71). Nazwy te funkcjonują na poziomie opisowym i wartościującym, co „skutkuje brakiem 
precyzji znaczeniowej, jak i przenoszeniem pozapoznawczych funkcji języka potocznego na teren języka naukowego" (s. 71). W efekcie termin jest wieloznaczny. W przekonaniu Autora istnieją co najmniej trzy podstawowe rozumienia tej nazwy:

- używana jest na oznaczenie szczególnej koncepcji (pedagogicznej), której zasadniczą tezą jest sprzeciw wobec „celowościowego wychowania",

- oznacza praktykę, sposób postępowania i myślenia, wolną od „roszczeń wychowawczych",

- określa się nią ruch społeczny, który „stawia sobie za cel walkę o prawa dzieci" (s. 73).

Z jednej strony wydaje się, że już samo określenie „antypedagogika” winno dezawuować ją jako inicjatywę wychowawczą; niektórzy umieszczają ją (także Autor) wśród „metateorii wychowania” (s. 74). Z drugiej strony, walcząc z wychowaniem, jednak ,podejmuje rozważania dotyczące podstawowych problemów istotnych dla wychowania" (s. 75); dokonuje się to na innej płaszczyźnie, tak zwanego wspierania, co w jakimś sensie odpowiadałoby zapoznanej (chyba) nauce o potencjonalności osoby ludzkiej (także osoby dziecka). Antypedagogiczny model relacji jej ideologowie przenoszą na relacje społeczne, obejmujące wszystkich (s. 76).

$\mathrm{W}$ ramach antypedagogiki odnotować należy też istnienie odrębnych nurtów. Wskazuje się na kierunek radykalny (krytyka teorii i praktyki wychowania), stanowisko promujące idee obrony praw dziecka (walka o prawa dziecka), ujęcie umiarkowane, które - tak się wydaje - prezentuje Hubertus von Schoenebeck (s. 30-31).

Mimo oczywistego argumentu przeciwko zaliczeniu antypedagogiki „do stanowisk pedagogicznych”, bo „trudno uznać za kierunek pedagogiczny taką koncepcję, która nie zawiera treści dotyczących wychowania, nie rozwija pozytywnie teorii wychowawczych, lecz swą uwagę ogniskuje na krytyce tego procesu” (s. 74), to jednak Autor uważa, że „spełnia, jak się wydaje, formalne kryteria decydujące o zaliczeniu jej do grona stanowisk,

${ }^{2}$ Określa się ją mianem „czarnej pedagogiki”. Jej przedstawiciele „są przekonani, że postulat odrzucenia wychowania odnosi się nie do jakiegoś specyficznego typu relacji wychowawczej, określonego modelu edukacji, lecz dotyczy wychowania jako takiego, w ogóle. Relacja wychowawcza strukturalnie zawiera agresję, nietolerancję, brak szacunku, podporządkowanie (...) każda próba wychowania nie tyle wspiera, co deformuje proces rozwoju dziecka, niszczy jego naturalną dynamikę". Piotr Magier, Esej postantypedagogiczny (Lublin: Towarzystwo Naukowe KUL, 2016), 30-31. 
nurtów w ramach pedagogiki. Mimo że treściowo odcina się ona od jakichkolwiek propozycji wychowawczych, deklarując swe stanowisko jako «poza» lub «przeciw», de facto podejmuje rozważania dotyczące podstawowych problemów istotnych dla wychowania. Proponując własny, specyficzny model relacji międzyludzkich, poddając analizie interpersonalną relację dziecko-osoba dorosła (rodzic, nauczyciel), przyjmuje określone koncepcje: człowieka, poznania, moralności, społeczeństwa - elementy stanowiące teoretyczną podstawę pedagogiki” (s. 74-75). Takie stanowisko zaskakuje, bo, stając wobec zła, o którym wie i z którym na dalszych stronach swej pracy się rozprawia, tu zajmuje stanowisko przyzwolenia na zło. Nie rozumiem tego.

Warto na koniec odnotować uwagi/zastrzeżenia Autora skierowane pod adresem antypedagogiki: „Chciałbym zauważyć, że teoria antypedagogiki przysparza wiele trudności badawczych i interpretacyjnych. Do głównych należą: (1) brak jednoznacznej, ostrej definicji antypedagogiki, powodujący odnoszenie tej nazwy do kilku stanowisk w myśli o wychowaniu; (2) brak okrzepłej, spójnej teorii antypedagogiki, spowodowany ciągłym i dynamicznym rozwojem tego nurtu; (3) eklektyczny charakter omawianej teorii; (4) nieostrość i wieloznaczność używanej przez antypedagogów terminologii, (5) często bardziej poetycki niż naukowy charakter wypowiedzi samych antypedagogów; (6) brak pogłębionej analizy teoretycznej własnego stanowiska, przy jednoczesnym skupieniu się na działalności społecznej, popularyzatorskiej oraz polemicznej" (s. 23).

Powstanie antypedagogiki w latach siedemdziesiątych ubiegłego stulecia przywodzi na pamięć protest pokolenia wychowanych bez ojców (1968) sierot drugiej wojny światowej. Poza tym przedrostek ,,anty-" wprowadza zamącanie rzeczywistości, element rewolucji, która destabilizuje, a nie buduje.

2. Istotne w procesie wychowania okazuje się rozumienie (ujęcie) człowieka. W formułowaniu antypedagogicznego stanowiska spotykamy się z tezami wziętymi z antropocentryzmu, subiektywizmu i relatywizmu, a przede wszystkim z humanizmu i postmodernizmu ${ }^{3}$; czasami ujęciami „,wypreparowanymi z kontekstu koncepcji macierzystej" (s. 34), formą jakiegoś bricolage' $u$, wpisanego w pajęczą sieć atrakcyjnie lub obrazoburczo brzmiących stwierdzeń, wyrazów ${ }^{4}$. Mamy tu do czynienia z:

${ }^{3}$, ,...) wydaje się, że teoretyczne «osadzenie» antypedagogiki stanowi głównie postmodernizm oraz humanizm” (s. 81). Szczegółowe rozpracowanie źródeł znajdzie Czytelnik na s. $32-70$.

4 ,Trudno niejednokrotnie ocenić, w jakim stopniu dany autor przejął czy przekształcił uprzednią myśl" (s. 32). 
- pajdocentryzmem 5 : człowiekiem jest dziecko, dorosły powinien stawać się dzieckiem. „Istota postawy antypedagogicznej ma polegać na rezygnacji z asymetrii relacji międzyosobowych, wyrażonej dominującą pozycją osoby dorosłej wobec dziecka" ${ }^{\prime 6}$ (s. 75); dorosły winien przysposabiać się do postaci dziecięcej, co więcej, sugeruje się konieczność „,przenoszenia antypedagogicznej kultury życia na wszelkie typy relacji interpersonalnych"” (s. 76);

- humanizmem antropocentrycznym, kierującym ku przyrodniczej interpretacji istoty człowieka;

- naturalizmem, którego rozwinięciem jest na przykład emotywizm, akcentujący idee swobody, autentyczności i spontaniczności jednostki: „Wartością poznawczą postpedagogiki jest spontaniczność" (s. 135);

- bałwochwalczym kultem człowieka: człowiek jest autonomicznym kreatorem, źródłem wolności i moralności;

- podkreśleniem znaczenia wiedzy intuicyjnej, „emocjonalnej” (s. 147), Kantowską zależnością opisu poznania u dzieci, tak zwanym „wyposażeniem kompetencji poznawczej”, a obecnie często niedającą się wyróżnić od inspiracji azjatyckich nurtów filozoficzno-religijnych;

- Kantowską interpretacją kwestii moralnej;

- odrzuceniem poznania pośredniego (dyskursywnego);

5 Należałoby powiedzieć o naiwnym (skrajnym) paidocentryzmie fundowanym na naturalizmie, naturalistycznym przeświadczeniu o dobroci natury ludzkiej, który daleki jest od ewangelicznego ,jeśli nie odmienicie się i nie staniecie się jak dzieci” (Mt 18, 2-3) czy filozoficznej refleksji nad dziecięctwem jako formą życia (Mieczysław A. Krąpiec).

6 „Osoba dorosła jest obecna w życiu dziecka jedynie jako towarzysz dziecka” (s. 138).

7 Takie stanowisko jest zrozumiałe w sytuacji skrajnego paidocentryzmu antypedagogiki: „Osoba dorosła poznaje dziecko tylko i wyłącznie na drodze empatii, przeżywania tych samych wydarzeń, co dziecko, uczestniczenia w jego życiu nie jako badacz, lecz jako przyjaciel i towarzysz" (s. 135). Jeszcze humanizm głosił, że ostatecznym kryterium oceny wartości celów w wychowaniu jest godność i dobro człowieka. Antypedagogika ,postuluje odejście od celów wychowaniu w ogóle” (s. 136), gdyż „celów obiektywnych, ich słuszności i obowiązywalności nie można uzasadnić" (s. 136).

8 „Intuicyjny charakter wiedzy nie przekreśla jej wartości poznawczej oraz praktycznej. Co więcej, traktowana jest ona jako bardziej adekwatna względem rzeczywistości niż wiedza racjonalna" (s. 147). 
- nadrzędnym znaczeniem przypisanym emocjom (s. 134), koncentracji na spontaniczności dziecka i ,wczuciu się",;

- rozumieniem rozwoju jako „kumulacji wszystkich doświadczeń i przeżyć" (s. 42);

- brakiem definiowalności osobowości.

3. Wydaje się, że antypedagogika jest sprzeciwem wobec absolutyzowania wiedzy, co jest zrozumiałe, bo nasze działanie nie jest pochodną tylko naszego rozumu uzbrojonego w wiedzę. Nie można jednak pozwolić sobie na lekceważące odniesienie do rozumu (prawdy), a jeżeli to się dzieje, to przynajmniej na pogardliwe odniesienie do źródeł, z których czerpie antypedagogika, traktując je wybiórczo i okazjonalnie.

- Mimo, że antypedagogika nie wyklucza „«obecności» rozumu w życiu psychicznym (poznawczym) człowieka, to zdecydowanie nadrzędne znaczenie przypisuje emocjom" (s. 134);

- „Humanistyczny charakter pedagogiki nie przeczy obecności w koncepcji tego nurtu biologicznej interpretacji natury człowieka. Nie jest jasne, jak antropolodzy godzą przekonania o przyrodniczym charakterze człowieka z przekonaniem o jego osobowym, wolnym, moralnym czy religijnym charakterze" (s. 134);

- Odrzucenie wychowania, które rozumie się jako „manipulację i urabianie mentalności jednostki" (s. 137), dokonuje się na rzecz edukacji, rozumianej jako „przekaz informacji (kształcenie)” (s. 137);

- „W ramach antypedagogiki funkcjonuje rozróżnienie na dwa typy kultury: patriarchalną i postpedagogiczną" (s. 141);

- Antypedagogika nie neguje transcendentnego aspektu egzystencji ludzkiej, ale zdecydowanie odrzuca pośredniczący charakter Objawienia, utożsamiając go z systemem patriarchalnym i asymetrycznością relacji.

4. Postpedagogika ze swym krytycyzmem wobec zdolności poznawczych rozumu przyjmuje ,postmodernistyczny dogmat” o tym, że nie ma prawdy obiektywnej, a każde poznanie jest jednostkowe, względne i subiektywne. „Poznawcze kompetencje jednostki zostały przeniesione z percepcji racjonalnej na poziom intuicji, odczuwania, emocji” (s. 196) co skutkuje:

9 „Nie chodzi tyle o „,czysto racjonalny, obiektywny przekaz treści opisujących rzeczywistość, co raczej o «spotkanie osób» - podmiotów w odmienny sposób interpretujących, przeżywających rzeczywistość, mających własną prawdę o świecie” (s. 40); „Zadaniem dorosłego jest «wsłuchać się», «wczuć się», zrozumieć i współodczuwać stany psychiczne oraz «wewnętrzny świat» dziecka" (s. 40-41). 
- Traktowaniem poznania jako projekcji apriorycznych kategorii (idei); ,mówi się o przynależnej każdemu człowiekowi od urodzenia zdolności, która umożliwia mu poznawczą orientację w rzeczywistości (tzw. kompetencję poznawczą)" (s. 36);

- podkreśleniem wartości „poznania indywidualnego, poznania konkretu, poznania intuicyjnego” oraz „bezpośredniego kontaktu przedmiotu poznającego z przedmiotem poznania" (s. 37);

- uznaniem przez antypedagogów za „niemiarodajne, upraszczające oraz ingerencyjne" (s. 135) empirycznych metod poznania;

- uznaniem spontaniczności za „wartość poznawczą” (s. 135).

Rozdział czwarty omawianej publikacji poświęcił Autor ocenie postpedagogicznych poglądów. Zastrzeżenie, że nie zawarto w nim skrystalizowanej koncepcji oceniającej, zdecydowanie odbiega od nachalnej, postmodernistycznej indoktrynacji antypedagogiki. Stawiając w nim pytania dotyczące metodologicznych i teoretycznych podstaw antypedagogiki, a także jej zaplecza filozoficznego oraz ideologicznych inspiracji, rozumnej refleksji Czytelnika pozostawiamy odpowiedź, czy z tych zmagań wyszedł zwycięsko.

Marek Marczewski*

\section{Elżbieta Kościńska, Zachowania ryzykowne seniorów. Uwarunkowania, profilaktyka, Bydgoszcz: Wydawnictwo Uniwersytetu Kazimierza Wielkiego, 2016, s. 198.}

DOI: http://dx.doi.org/10.12775/PCh.2017.039

Zagadnienia dotyczące starości i starzenia się człowieka ${ }^{1}$ są coraz częściej przedmiotem zainteresowania przedstawicieli rozmaitych dyscyplin naukowych ${ }^{2}$. Przyczyną tego jest niewątpliwie wzrost populacji ludzi starszych

* Dr hab. Marek Marczewski, prof. WSSE, jest profesorem w Wyższej Szkole Społeczno-Ekonomicznej w Gdańsku. Adres: Wyższa Szkoła Społeczno-Ekonomiczna w Gdańsku, ul. Rajska 6,80-850 Gdańsk; e-mail: mamarcz@wp.pl.

${ }^{1}$ Por. Halina Worach-Kardas, Starość w cyklu życia. Spoleczne i zdrowotne oblicza późnej dorostości (Katowice: „Śląsk”, 2015), 15-36.

${ }^{2}$ Norbert Pikuła, Etos starości w aspekcie społecznym. Gerontologia dla pracowników socjalnych (Kraków: Wyższa Szkoła Filozoficzno-Pedagogiczna Ignatianum, Wydawnictwo WAM, 2011), 11. 